Int. J. Morphol.,

31(2):590-593, 2013

\title{
Complete Ossification of the Superior Transverse Scapular Ligament in an Turkish Male Adult
}

\author{
Osificación Completa del Ligamento Escapular Superior \\ Transverso en un Hombre Adulto de Turquía
}

Büyüikmumcu, M.*; Seker, M.*; Ozbek, O.*; Akın, D."; Koc, O.**; Aydın, A. D.* \& Salbacak, A.*

BÜYÜKMUMCU, M.; SEKER, M.; OZBEK, O.; AKIN, D.; KOC, O.; AYDIN, A. D. \& SALBACAK, A. Complete ossification of the superior transverse scapular ligament in an Turkish male adult. Int. J. Morphol., 31(2):590-593, 2013.

SUMMARY: Scapula has three margins and angles and located posterolateral of thorax. One of the anatomical structures of scapula is suprascapular notch located medial to coracoid process base. Suprascapular notch can be seen in different shapes and depths. Suprascapular notch is surrounded by transverse scapular ligament which is a short and strong ligament. Suprascapular notch creates an osteofibrosis passage with this structure within suprascapular nerve passes. It has been reported that this osteofibrosis structure can intirely or partially ossify. All lesions of nerves occured in course as result of exposure to compression, tension and bending are called entrapment neuropathy. Like other peripheral nerves, suprascapular nerve can be exposed to compression while passing suprascapular notch. As a result of this compression suprascapular entrapment neuropathy may occur. There are direct trauma, repetitive microtrauma, neurit, progressive compressive lesions in suprascapular entrapment neuropathies etiology. A suprascapular notch taken foramen shape can be a predisposing factor to entrapment neuropathy. In the retrospective screening from Necmettin Erbakan University, Meram Medical Faculty, Department of Radiology archive, a male patient at age 68 with suprascapular notch variation has been detected. This patient's right suprascapular notch had became foramen by an osseous bridge. Diameters of foramen has been measured as $5.27 \mathrm{~mm}$ transverse $6.48 \mathrm{~mm}$ vertical. We believe having detailed knowledge of suprascapular notch is significant as a possible course of back and shoulder pain is entrapment of suprascapular nerve in suprascapular notch causing nerve paralyses, and it will give a right direction to clinicians in surgical practices.

KEY WORDS: Suprascapular notch; Multidetector Computed Tomography; Variations.

\section{INTRODUCTION}

Scapula is a three margined and three angled bone located posterolateral of thorax. Suprascapular notch is one of the anatomical structures on scapulae. It is located on superior margin of scapulae medial to base of coracoid process. The suprascapular notch can be seen in different shapes and have different depths. This notch is surrounded with superior transverse scapular ligament which is a short and strong ligament. Suprascapular nerve passes under this ligament and suprascapular artery and vein pass over this ligament together. As well as the superior transverse scapular ligament can be formed with multiple parts, rarely it can become a foramen due to ossification. Peripheral nerves have different courses on body. All lesions ocurred due to forces like pressure, tension and bending during these courses are called entrapment neuropathy. Suprascapular nerve can also be exposed to pressure in suprascapular notch. As a result of this pressure suprascapular entrapment neuropathy first described by Thompsen \& Kopel (1959) can occur. Clinical appereance contains complaints of common and intense pain on shoulder and back. Among the causes there are congenital abnormalities of suprascapular notch, repeated microtraumas, direct traumas resulted fracture of scapulae, shape and quantitative variations of inferior and superior transverse scapular ligament inflamatory diseases like neuritis and some other reasons causes pressure on suprascapular nerve (Poirier \& Charpy, 1911; Vallois, 1925; Gray, 1942; Moskowitz \& Rashkoff, 1989; Bruns \& Gruber, 1989; Thompson \& Kopel).

\footnotetext{
* Department of Anatomy, Meram Medicine Faculty, Necmettin Erbakan University, Konya, Turkey.

*** Department of Radiology, Meram Medicine Faculty, Necmettin Erbakan University, Konya, Turkey.
} 


\section{CASE REPORT}

In our study a 68 year-old patients multi detector computer tomography image obtained from Radiology department of Necmettin Erbakan University Meram Medical Faculty is used. No variations have been observed
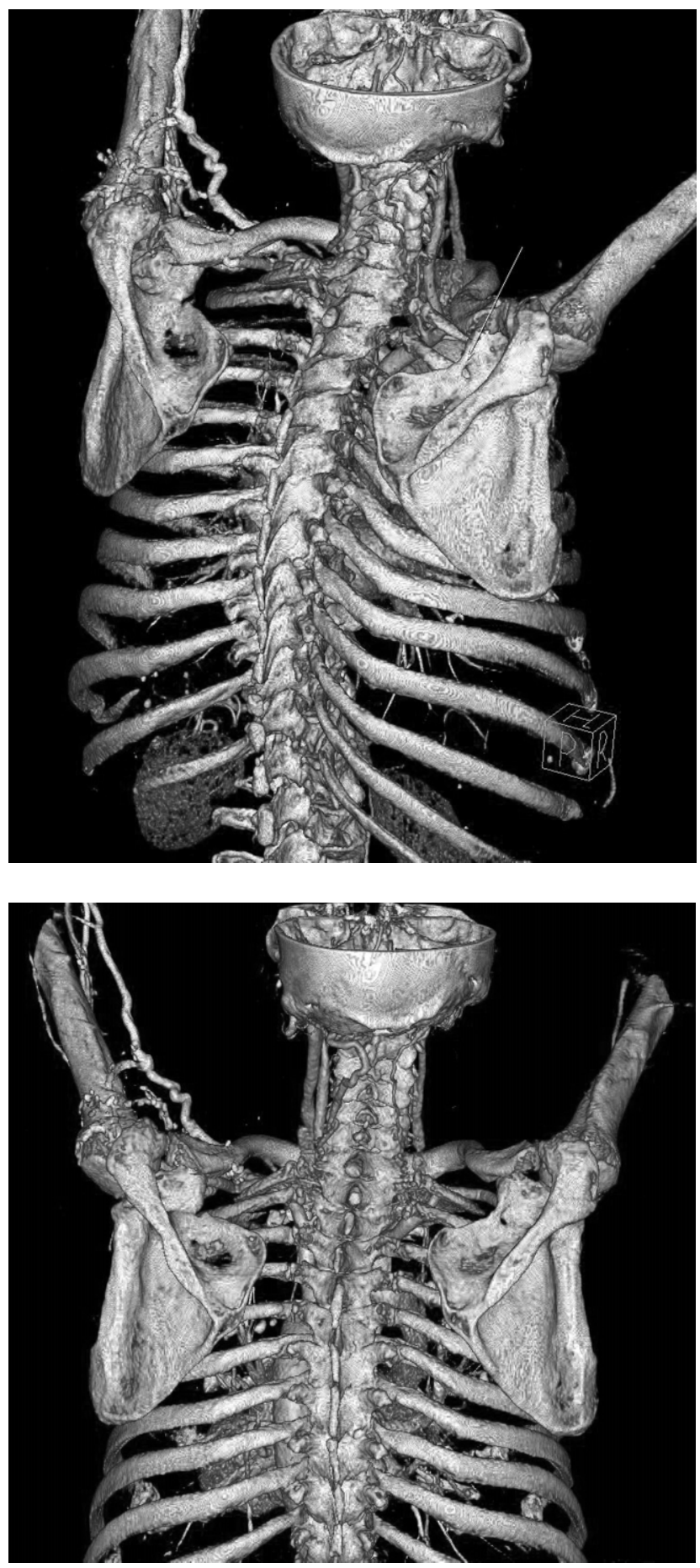

on patients left suprascapular notch on the other hand right suprascapular notch have been observed became a foramen due to ossification of superior transverse scapular ligament. This foramen had $5.27 \mathrm{~mm}$ of transverse diameter and 6.48 mm of vertical diameter.

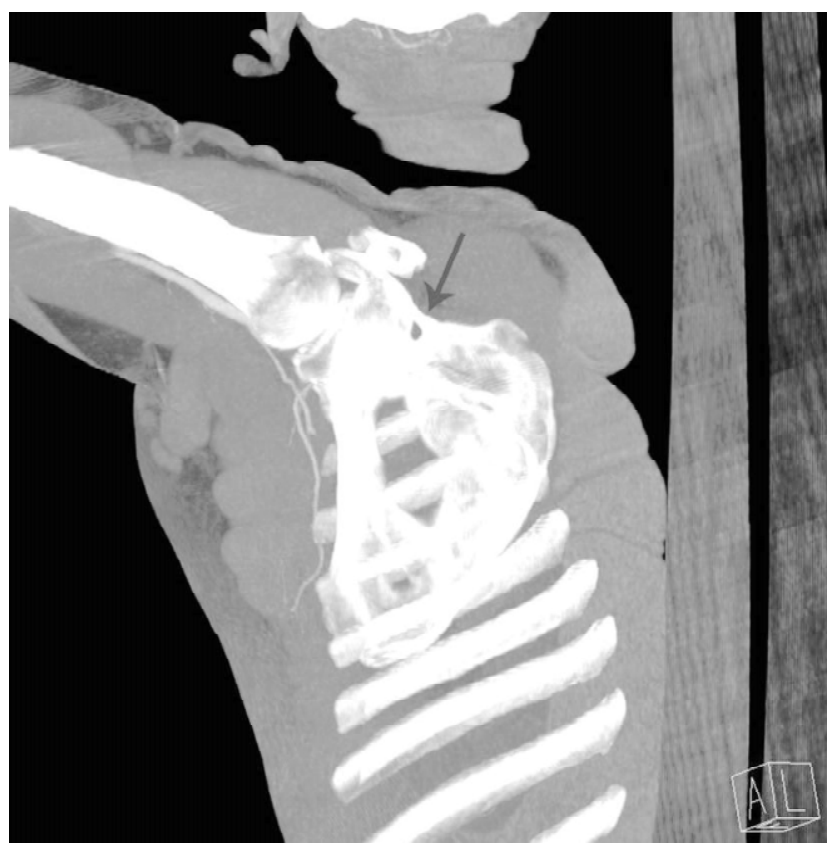

Figs. 1,2 and 3. Ossification of superior transverse scapular ligament

\section{DISCUSSION}

Suprascapular nerve is a mixed peripheral nerve. Motor branches of this nerve innerve infraspinatus and supraspinatus muscles. Sensory fibers don't spread on skin. These fibers innerve capsules and ligaments of shoulder joint and acromioclavicular joint. Therefore pressure on this nerve causes atrophy on infraspinatus and supraspinatus muscles. Also shoulder and back pain is seen (Moskowitz \& Rashkoff; Bruns \& Gruber; Thompson \& Kopel; Garcia \& Mcqueen, 1982; Hrdlicka, 1942).

First studies shows suprascapular notch becomes a foramen due to ossification of superior transverse scapular ligament are made by Poirier \& Charpy in 1911. In their study they had encountered 3 of 60 cases with foramen (5\%). In 1925, Vallois stated the rate as $6.5 \%$ after his studies on french. Gray stated 73 foramen from total of 1151 scapulaes. 
There are also case studies on different races by researchers like Osuagwu et al. (2005); Silva et al. (2007); Das et al. (2007), and Khan (2006). Semptoms appeared by pressure on suprascapular nerve are first described by Thompson \& Kopel. They reported superior transverse scapular ligament can pressure suprascapular nerve during the motion of abduction and adduction of both armes. With this Hama et al. (1992), and Cohen et al. (1997), reported that with loss of sensory of rotator muscles innerved by suprascapular nerve abduction and external rotation motions would be limited and painfull in process.

Zeiss et al. (1993), reported the rate of $10 \%$ superior transverse scapular ligament turnes into a complete ossifiyed channel after their study with MRI. Other than that they reported an suprascapular notch turned into a foramen can put a complete pressure on suprascapular nerve and course paralysis of supraspinatus and infraspinatus muscles. According to Alon et al. (1988), suprascapular nerve pressure can consist due to congenital anomalies of superior transverse scapular ligament mostly occured by forward bending of shoulder. Cohen et al., suggested suprascapular entrapment neuropathy can have a genetic substructure. In their study, they had reported weakness of external rotation and abduction, atropy on supraspinatus muscle and local pain complaints of a 58 year-old patient and his son, and they had reported entrapment neuropathy due to calsification of suprascapular notch in both.

As result; superior transverse scapular ligament taken shape of foramen due to ossification can be a predisposing factor of "suprascapular entrapment neuropathy" because of its pressure on suprascapular nerve. As a result of this pressure suprascapular nerve entrapment may occur. Therefore, having detailed anatomical knowledge of superior transverse scapular ligament lends assistance to explaining possible suprascapular nerve paralyses. We also think that on surgical practices knowledge of variations of this ligament will give a right direction to the operation.

BÜYÜKMUMCU, M.; SEKER, M.; OZBEK, O.; AKIN, D.; KOC, O.; AYDIN, A. D. \& SALBACAK, A. Osificación completa del ligamento escapular superior transverso en un hombre adulto de Turquía. Int. J. Morphol., 31(2):590-593, 2013.

RESUMEN: La escápula tiene tres márgenes y tres ángulos, y se encuentra en la región posterolateral del tórax. Una de las estructuras anatómicas de la escápula es la incisura supraescapular situada medial a la base del proceso coracoides. La incisura supraescapular puede tener diferentes formas y profundidad. Está rodeada por el ligamento escapular transverso, un ligamento corto y fuerte. Con esta estructura, crea un pasaje osteofibroso por el cual pasa el nervio supraescapular. Se ha reportado que esta estructura osteofibrosa se puede osificar completa o parcialmente. Todas las lesiones de los nervios ocurren en su trayecto como resultado de la exposición a compresión, tensión y flexión, lo que se denomina neuropatía por atrapamiento. El nervio supraescapular puede estar expuesto a compresión al pasar por la incisura supraescapular, generando neuropatía por atrapamiento. Su etiología puede ser por traumatismo directo, microtraumatismo repetitivo y lesiones compresivas progresivas. Una incisura supraescapular de forma oval puede ser un factor predisponente para la neuropatía por atrapamiento. En un estudio retrospectivo realizado en la Universidad Necmettin Erbakan, Facultad de Medicina de Meram, Departamento de archivo de Radiología, se observó la imagen de un varón de 68 años con variación en la incisura supraescapular derecha, la cual se transformó en un foramen por un puente óseo. Los diámetros del foramen fueron $5,27 \mathrm{~mm}$ transversales y $6,48 \mathrm{~mm}$ verticales. Creemos que el conocimiento detallado de la incisura supraescapular es necesario en el diagnóstico y posible curso de dolor del hombro, debido al atrapamiento del nervio supraescapular en la incisura y la posible parálisis nerviosa, dando una guía a los clínicos en las prácticas quirúrgicas.

PALABRAS CLAVE: Incisura supraescapular; Tomografía computarizada multidetector; Variaciones.

\section{REFERENCES}

Alon, M.; Weiss, S.; Fishel, B. \& Dekel, S. Bilateral suprascapular nerve entrapment syndrome due to an anomalous transverse scapular ligament. Clin. Orthop. Relat. Res., (234):31-3, 1988.

Bruns, J. \& Gruber, H. Blockade of the suprascapular nerve in shoulder pain. Anasth. Intensivther. Notf. Med., 24(2):100-2, 1989.

Cohen, S. B.; Dines, D. M. \& Moorman, C. T. Familial calcification of the superior transverse scapular ligament causing neuropathy. Clin. Orthop. Relat. Res., (334):131-5, 1997.
Das, S.; Suri, R. \& Kapur, V. Ossification of superior transverse scapular ligament and its clinical implications. Sultan Qaboos Univ. Med. J., 7(2):157-60, 2007.

Garcia, G. \& Mcqueen, D. Bilateral suprascapular nerve entrapment syndrome. J. Bone Joint Surg. Am., 63(3):491-2, 1982.

Gray, D. J. Variations in the human scapulae. Am. J. Phys. Anthropol., 29(1):57-72, 1942.

Hama, H.; Ueba, Y.; Morinaga, T.; Suzuki, K.; Kuroki, H. \& 
BÜYÜKMUMCU, M.; SEKER, M.; OZBEK, O.; AKIN, D.; KOC, O.; AYDIN, A. D. \& SALBACAK, A. Complete ossification of the superior transverse scapular ligament in an Turkish male adult.Int. J. Morphol., 31(2):590-593, 2013.

Yamamuro, T. A new strategy for treatment of suprascapular entrapment neuropathy in athletes: Shaving of the base of the scapular spine. J. Shoulder Elbow Surg., 1(5):253-60, 1992.

Hrdlicka, A. The scapula: visual observations. Am. J. Phys. Anthropol., 29(1):73-94, 1942.

Khan, M. A. Complete ossification of the superior transverse scapular ligament in an Indian male adult. Int. J. Morphol., 24(2):195-6, 2006.

Moskowitz, E. \& Rashkoff, E. S. Suprascapular nerve palsy. Conn. Med., 53(11):639-40, 1989.

Osuagwu, F. C.; I'mosemi, I. O. \& Shokunbi, M. T. Complete ossification of the superior transverse scapular ligament in a Nigerian male adult. Int. J. Morphol., 23(2):121-2, 2005.

Poirier, P. \& Charpy, A. Traite d'Anatomia Humaine. $3^{\text {th }}$ ed. Paris, Masson, 1911.

Silva, J. G.; Abidu-Figueiredo, M.; Fernandes, R. M. P.; AurelianoRafael, F. Sgrott, E. F.; Silva, S. F.; et al. High incidence of complete ossification of the superior transverse scapular ligament in the Brazilians and its clinical implications. Int. J. Morphol., 25(4):855-9, 2007.

Thompson, W. P. L. \& Kopel, H. B. Peripheral entrapment neuropathies of the upper extremity. N. Engl. J. Med., 260(25):1261-5, 1959

Vallois, H. V. L'os acromial dans les races humaine. L' Anthropologie, Paris, 35:977-1022, 1925.

Zeiss, J.; Woldenberg, L. S.; Saddemi, S. R. \& Ebraheim, N. A. MRI of suprascapular neuropathy in a weight lifter. J. Comput. Assist. Tomogr., 17(2):303-8, 1993.
Correspondence to: Mustafa Büyükmumcu Necmettin Erbakan University Meram Medicine Faculty Department of Anatomy, Konya TURKEY

Email:mbmumcu66@yahoo.com

Received: 03-10-2012

Accepted: 01-03-2013 